\title{
Autoradiographic Localization and Characterization of Atrial Natriuretic Peptide Binding Sites in the Rat Central Nervous System and Adrenal Gland
}

\author{
Thomas R. Gibson, Gary M. Wildey, Scott Manaker, ${ }^{1}$ and Christopher C. Glembotski \\ Department of Pharmacology, School of Medicine, University of Pennsylvania, Philadelphia, Pennsylvania 19104
}

\begin{abstract}
Atrial natriuretic peptides (ANP) have recently been identified in both heart and CNS. These peptides possess potent natriuretic, diuretic, and vasorelaxant activities, and are all apparently derived from a single prohormone. Specific ANP binding sites have been characterized in the adrenal zona glomerulosa and kidney cortex, and one study reported ANP binding sites in the CNS. However, a detailed examination of the localization of ANP binding sites throughout the brain has not been reported. In this study, quantitative autoradiography was employed to examine the distribution of ANP receptors in the rat CNS. The binding of (3- ${ }^{125}$ I-iodotyrosyl ${ }^{28}$ ) rat ANP-28 to binding sites in the rat CNS was saturable, specific for ANP-related peptides, and displayed high affinity $\left(K_{\mathrm{d}}=600 \mathrm{pM}\right)$. When the relative concentrations of ANP binding sites were determined throughout the rat brain, the highest levels of ANP binding were localized to the circumventricular organs, including the area postrema and subfornical organ, and the olfactory apparatus. Moderate levels of ANP binding sites were present throughout the midbrain and brain stem, while low levels were found in the forebrain, diencephalon, basal ganglia, cortex, and cerebellum. The presence of ANP binding sites in the subfornical organ and the area postrema, regions considered to be outside the blood-brain barrier, suggests that peripheral ANP levels may regulate some aspects of CNS control of salt and water balance. The possible functions of ANP binding sites in other regions of the rat brain are not known, but, like many other peptides, ANP may act as a neurotransmitter or neuromodulator at these loci.
\end{abstract}

Much interest has becn gencrated by the recent discovery of bioactive peptides within cardiac atria. These peptides, collectively referred to as atrial natriuretic factor (ANF) or peptides (ANP), have been shown to exhibit natriuretic, diuretic, and vasorelaxant activities in several bioassay model systems (Currie et al., 1983; DeBold ct al., 1981). ANP is also suggested to have an inhibitory effect on adrenal steroidogenesis (Matsuoka et al., 1985). Although many bioactive peptides of varying size have been purified from atrial tissue, all contain common amino acid sequences (Atlas et al., 1984; Currie et al., 1984), suggesting

Received Aug. 15, 1985; revised Jan. 9, 1986; accepted Jan. 9, 1986.

This work was supported by National Institutes of Health Grant NS20396, American Heart Association Grant-in-aid 84 653, with funds contributed in part by the Philadelphia Chapter of the American Heart Association, and Biomedical Research Support Grants S07-05415-23 and -24, and Medical Scientist Training Program Grant 5-T32-GM07170 awarded by the NIH. T.R.G. is a Special Investigator of the American Heart Association, Southeastern Pennsylvania Chapter, and C.C.G. is an Established Investigator of the American Heart Association. We would like to thank Barry Wolfe, Richard Miselis, and Paul Shields for their comments during the preparation of this manuscript.

Correspondence should be addressed to Thomas R. Gibson, Department of Pharmacology/G3, University of Pennsylvania, 36th and Hamilton Walk, Philadelphia, PA 19104.

Present address: Department of Medicine, Boston City Hospital, Boston, MA. Copyright (C) 1986 Society for Neuroscience $0270-6474 / 86 / 072004-08 \$ 02.00 / 0$ that these peptides may be shorter fragments of a large, common precursor. The isolation and characterization of both rat (Maki et al., 1984; Yamanka et al., 1984) and human (Oikawa et al., 1984) cloned atrial cDNA encoding for ANP supports the hypothesis that all ANP-related peptides isolated to date can be generated from a common preprohormone.

ANP is one of many peptides originally discovered and characterized in peripheral organs and subsequently shown to exist in the CNS (Iversen, 1983; Krieger, 1983). ANP-related peptides have been found in particularly high concentrations in the pons and hypothalamus, using both immunohistochemistry (Jacobowitz et al., 1985; Saper et al., 1985) and radioimmunoassay (Tanaka et al., 1984). In addition, different forms of ANP-related peptides are found in the rat hypothalamus, atria, and plasma (Glembotski et al., 1985; Morii et al., 1985; Tanaka et al., 1984). Therefore, ANP-related peptides may also be important physiological regulators of fluid balance through centrally mediated mechanisms.

ANP-related peptides are thought to produce their physiological effects by interacting with specific surface receptors on appropriate target tissues. Utilizing radioligand binding techniques, high-affinity (picomolar) binding sites for ANP have been identified and characterized on membranes derived from rabbit aorta, rabbit and rat kidney (Napier et al., 1984), and bovine adrenal cortex (Currie et al., 1984). Specific binding sites with lower affinity (nanomolar) for ANP have also been shown to exist on cultured rat vascular smooth muscle cells (Hirata et al., 1984). That these binding sites described by radioligand binding techniques are biologically relevant is suggested by 2 observations: (1) their affinities for ANP-related peptides are similar to the reported plasma concentrations of immunoreactive ANP (Tanaka et al., 1984), and (2) the ability of various ANP analogs to inhibit the binding of labeled ANP to highaffinity membrane sites parallels the bioactive potencies of these analogs (DeLean et al., 1984; Napier et al., 1984).

ANP binding sites in the rat brain have been demonstrated using autoradiography (Quirion et al., 1984). The autoradiographic distribution of these binding sites was found to be unique compared to other peptide receptors, and binding was not inhibited by other peptide hormones or neurotransmitters. This report, however, did not contain quantitative data characterizing these central ANP binding sites. In the present report we utilize quantitative autoradiography to localize and characterize the ANP binding sites in the rat brain and adrenal gland.

\section{Materials and Methods}

\section{Terminology}

Sincc conflicting terminology has evolved in describing various ANPrelated peptides, the following standard abbreviations will be used throughout this paper: ANP-28, atrial natriuretic peptide-28 or proANP(99-126); AP III, atriopeptin III or pro-ANP(103-126); AP I, atrio- 
peptin I or pro-ANP(103-124); and ANP(13-28), atrial natriuretic peptide (13-28) or pro-ANP(111-126).

\section{Animals}

ANP receptor levels were measured in brain and adrenal tissue taken from male Sprague-Dawley rats (150-200 gm; Charles River Breeding Labs Inc., Wilmington, MA). The rats were housed under a 14:10 hr light-dark cycle and were maintained with Purina rat chow and water ad libitum.

\section{Chemicals and peptides}

Rat ANP-28, AP I, AP III, ANP(13-28), adrenocorticotropic hormone (ACTH), $\alpha$-melanocyte-stimulating hormone ( $\alpha \mathrm{MSH})$, thyrotropin-releasing hormone (TRH), D-Ala-D-Leu-enkephalin (DADLE), and $\beta$-endorphin were obtained from Peninsula Laboratories (Belmont, $C A$ ) or Bachem (Torrance, CA). (3-125I-iodotyrosyl ${ }^{28}$ ) rat ANP-28 (25I-ANP$28 ; 1920-2000 \mathrm{Ci} / \mathrm{mmol}$ ) was purchased from Amersham (Arlington Heights, IL). Biochemicals were obtained from Sigma Chemical Co. (St. Louis, MO), and all other compounds were reagent grade.

\section{Tissue preparation}

For regional localization by quantitative autoradiography, animals were decapitated and their brain tissue rapidly removed, mounted on cryostat chucks, and frozen in dry ice. Coronal sections $(32 \mu \mathrm{m})$ were cut at $-18^{\circ} \mathrm{C}$ and thaw-mounted onto chromate/gelatin-subbed slides. Sections were then stored with desiccant at $-20^{\circ} \mathrm{C}$. Four consecutive sections at $500 \mu \mathrm{m}$ intervals were mounted, 2 per slide, for total and nonspecific binding determinations.

For the biochemical characterization of ${ }^{125}$ I-ANP-28 binding siles, 2 methods were employed. First, for analysis by gamma counting, olfactory bulbs or adrenal glands were obtained from freshly killed rats and quickly frozen on dry ice. This tissue was then thawed, minced, and homogenized to form a tissue mash. This mash was then placed into a $3 \mathrm{ml}$ plastic syringe and frozen, and sections $(32 \mu \mathrm{m})$ were cut and thawmounted ( 2 sections per slide). Second, for densitometric studies, olfactory bulb or adrenal tissue was mounted directly onto cryostat chucks and frozen; then, $32 \mu \mathrm{m}$ sections were cut and thaw-mounted (2-4 sections per slide). All sections were stored desiccated at $-20^{\circ} \mathrm{C}$ until needed.

\section{Binding procedures}

Slides were warmed to room temperature and preincubated for $10 \mathrm{~min}$ in slide jars filled with buffer $(50 \mathrm{~mm}$ Tris- $\mathrm{HCl}, 150 \mathrm{~mm} \mathrm{NaCl}, 5 \mathrm{~mm}$ $\mathrm{MgCl}_{2}, 0.1 \% \mathrm{BSA}, \mathrm{pH} 7.4$ ) at $25^{\circ} \mathrm{C}$. After preincubation, sections were allowed to air-dry for at least $1 \mathrm{hr}$ at $4^{\circ} \mathrm{C}$. Slides were then incubated with $300 \mu \mathrm{l}$ (whole-brain slices) or $200 \mu \mathrm{l}$ (olfactory bulb and adrenal mash and slices) of $4^{\circ} \mathrm{C}$ buffer containing $5 \mu \mathrm{g} / \mathrm{ml}$ leupeptin, $10 \mu \mathrm{M}$ bestatin, and varying concentrations of ${ }^{125}$ I-ANP-28. These volumes were sufficient to cover completely both sections on a slide. Since the binding of ${ }^{125}$ I-ANP-28 was shown to reach equilibrium after $90 \mathrm{~min}$ (not shown), the sections were incubated at $4^{\circ} \mathrm{C}$ for $2 \mathrm{hr}$; more than $95 \%$ of the iodinated ligand co-eluted with ${ }^{125}$ I-ANP- 28 standard on RP-HPLC (Glembotski et al., 1985) after the incubation. They were then washed with $4^{\circ} \mathrm{C}$ buffer 4 times for $15 \mathrm{~min}$ cach. Preliminary experiments established that little specific binding was lost by this procedure, and fewer washes after incubation resulted in a greater proportion of nonspecific binding. For gamma counting, the sections were wiped off the slides with Schleicher and Schuell no. 30 glass-fiber filter disks, placed in tubes, and counted in an LKB Minigamma gamma counter. For autoradiography, the slides were briefly dipped in $4^{\circ} \mathrm{C}$ distilled water to remove buffer salts and then rapidly dried on a 60 $70^{\circ} \mathrm{C}$ slide drier.

Concentrations of ${ }^{125}$ I-ANP-28 employed were 50 pM for studies of regional localization and for inhibition analysis, and from 35 to 1000 pM for Scatchard analysis. For inhibition analysis, 10 concentrations of unlabeled ANP-related peptides spanning 5 orders of magnitude were included; other compounds were included at concentrations indicated in the text. Nonspecific binding was defined as the binding of ${ }^{25}$ I-ANP28 in the presence of $100 \mathrm{nM}$ AP III. At 50 pM ${ }^{125}$ I-ANP-28, specific binding in sections of tissue mash was $50-70 \%$ of total binding (1000$2000 \mathrm{cpm}$ ).

\section{Quantitative densitometry}

Quantitative autoradiograms of ${ }^{125}$ I-ANP-28 binding to tissue sections were prepared as described previously (Rainbow et al., 1982). Sections were apposed to LKB Ultrofilm (LKB, Inc., Gaithersburg, MD), exposed at room temperature for $5 \mathrm{~d}$, and developed.

Densitometric analysis of autoradiograms was performed as described previously (Rainbow et al., 1982, 1984; Unnerstall et al., 1982). Optical density values were converted into $\mathrm{fmol} / \mathrm{mg}$ of protein using ${ }^{125} \mathrm{I}$ standards prepared from brain mash mixed with known quantities of ${ }^{125} \mathrm{I}$ $\alpha$ MSH (Rainbow et al., 1984; Unnerstall et al., 1982). Values for total and nonspecific binding of ${ }^{125}$ I-ANP-28 for each brain region were obtained by averaging 4-8 readings of the 2 sections on each autoradiogram. Equal numbers of readings were taken bilaterally and averaged together. After autoradiography, the sections were stained with cresyl violet to allow the overlaying of the section and autoradiogram for localization of the binding to specific brain structures. For Scatchard and inhibition analyses, the plexiform layer of the olfactory bulb and the zona glomerulosa of the adrenal gland were analyzed utilizing the techniques described above.

\section{Results}

Scatchard analysis of ${ }^{175} I-A N P-28$ binding to olfactory bulb mash by gamma counting

Linear Scatchard plots were generated by varying the concentration of radiolabeled ligand from 50 to 1000 pM. A $K_{d}$ of $567 \pm$ $178 \mathrm{pm}$ (mean of 3 experiments \pm SEM) was obtained, with a $B_{\max }$ of $9.8 \pm 2.0 \mathrm{fmol} / \mathrm{mg}$ protein.

Inhibition analysis of ${ }^{125} I-A N P-28$ binding to olfactory bulb and adrenal mash by gamma counting

When unlabeled ANP-related peptides were added to the incubation mixture, differing potencies of inhibition were obtained (Table 1). AP III and ANP-28, comprising the 24 and $28 \mathrm{COOH}$-terminal amino acids of pro-ANP, respectively, inhibited the binding of ${ }^{125}$ I-ANP-28 by $50 \%$ with low nanomolar potency. At peptide concentrations higher than $100 \mathrm{nM}$, the competition curves were no longer monophasic, with an apparent low-affinity binding component. This low-affinity binding component has been reported previously for ANP binding (DeLean, 1984; Napier et al., 1984) and was not examined in the present study. AP I, which is COOH-terminally shortened by 2 amino acids as compared to AP III, inhibited the binding of ${ }^{125}$ I-ANP-28 to olfactory bulb mash only at higher nanomolar concentrations. ANP(13-28) - which does not contain both cysteine residues, and thus does not have the disulfide bond that is present in longer ANP-related peptides-failed to block the binding of the radiolabeled ligand even at a concentration of 10 $\mu \mathrm{M}$. Inhibition of binding of ${ }^{125}$ I-ANP-28 to adrenal mash by ANP-related peptides had a similar profile, although inhibition by AP I seemed to be more potent. Other peptide hormonesincluding TRH, DADLE, ACTH, $\alpha \mathrm{MSH}$, insulin, and $\beta$-endorphin (all at $1 \mu \mathrm{M}$ )-were unable to compete for the binding of ${ }^{125}$ I-ANP-28 in olfactory bulb mash. Propranolol, phentolamine, atropine (all at $10 \mu \mathrm{M}$ ), and carbachol (1 mM) were also ineffective.

\section{Densitometric characterization of ${ }^{225} I-A N P-28$ binding to olfactory bulb and adrenal sections}

Frozen sections of olfactory bulb and adrenal tissue were incubated in the presence of ${ }^{125} \mathrm{I}-\mathrm{ANP}-28$ and various concentrations of unlabeled ANP-related peptides. The resulting autoradiograms were quantified by densitometry for inhibition analysis. The $\mathrm{IC}_{50}$ values calculated for olfactory bulb sections (Table 1) correspond closely to results obtained utilizing olfactory bulb mash as described above. The $\mathrm{IC}_{50}$ value for ANP-28 in adrenal sections of $0.84 \pm 0.20 \mathrm{nM}$ (not shown) also agrees with the data obtained using adrenal mash (Table 1). Scatchard analysis of incubation mixtures containing $50-1000$ pM ${ }^{125} \mathrm{I}-$ ANP-28 was also performed on sections of olfactory bulb, and a $K_{\mathrm{d}}$ of $630 \mathrm{pM}$ and $B_{\max }$ of $31.9 \mathrm{fmol} / \mathrm{mg}$ protein were obtained. This $K_{\mathrm{d}}$ value is similar to that obtained by Scatchard analysis 
Table 1. Relative potencies of ANP-related peptides in inhibiting ${ }_{125}$ I-AP-28 binding to rat olfactory bulb and adrenal sections

\begin{tabular}{|c|c|c|c|}
\hline \multirow[b]{2}{*}{ Compound } & \multicolumn{3}{|l|}{$\underline{\mathrm{IC}_{50}(\mathrm{nM})}$} \\
\hline & $\begin{array}{l}\text { Mash, } \\
\text { olfactory }\end{array}$ & $\begin{array}{l}\text { Tissue, } \\
\text { olfactory }\end{array}$ & $\begin{array}{l}\text { Mash, } \\
\text { adrenal }\end{array}$ \\
\hline AP-28 & $0.98 \pm 0.05$ & $0.52 \pm 0.13$ & $1.89 \pm 0.28$ \\
\hline AP III & $0.96 \pm 0.32$ & $1.13 \pm 0.44$ & $2.90 \pm 1.14$ \\
\hline AP I & $16.76 \pm 6.19$ & $17.54 \pm 6.21$ & $2.16 \pm 1.43$ \\
\hline ANP(13-28) & $>1000$ & ND & $>1000$ \\
\hline
\end{tabular}

Several concentrations of ANP-related peptides were tested for their abilities to inhibit the binding of 50 pM ${ }^{125}$ I-AP-28. Binding was assayed by gamma counting for mash sections or autoradiography for tissue sections as described in Materials and Methods. Values are expressed as means \pm SE for 3-5 experiments. ND, not determined.

of olfactory bulb mash described above, while the higher $B_{\max }$ value reflects the concentration of binding sites to only a specific layer of the olfactory bulb.

\section{Densitometric quantitation of regional binding}

The distribution of atrial natriuretic peptide binding sites in individual nuclei and subregions of rat brain was discrete and heterogeneous (Fig. 1). Moderately high (1.0-2.0 fmol $/ \mathrm{mg}$ protein) to very high (2.0-4.0 fmol/mg protein) levels of ${ }^{125} \mathrm{I}-\mathrm{ANP}$ 28 binding sites were localized within the circumventricular organs and the olfactory apparatus (Table 2). Moderate levels (0.5-1.0 fmol $/ \mathrm{mg}$ protein) of ANP binding sites were present throughout the midbrain and brain stem. Low levels $(<0.5 \mathrm{fmol} /$ mg protein) of ${ }^{125} \mathrm{I}-\mathrm{ANP}-28$ binding sites were observed throughout the forebrain, diencephalon, basal ganglia, cortex, and cerebellum. Moderate to low levels of ${ }^{125}$ I-ANP-28 binding sites were present in some white matter structures. Nonspecific binding was relatively homogeneous, ranging between 0.5 and 1.0 $\mathrm{fmol} / \mathrm{mg}$ protein.

The accessory olfactory bulb contained the highest level of ${ }^{125}$ I-ANP-28 binding sites within the rat CNS (3.13 $\pm 0.10 \mathrm{fmol} /$ mg protein). The plexiform layers of the olfactory bulb also were very high in ANP binding sites $(1.97 \pm 0.11 \mathrm{fmol} / \mathrm{mg}$ protein). This value suggests that, under the conditions used in this experiment, the fractional occupancy of these binding sites is about $6 \%$, by comparison with the $B_{\max }$ valuc of $31.9 \mathrm{fmol} / \mathrm{mg}$ protein (see above). Other layers of the olfactory bulb (granular, glomerulosa) contained moderate levels of ANP binding sites. Within white matter regions of the olfactory apparatus, the lateral olfactory tract possessed moderately high levels of ANP binding sites throughout its rostrocaudal extent, while the olfactory nerve contained only moderate levels of ANP binding sites.

The circumventricular organs were noted to have a highly heterogeneous distribution of ANP binding sites. The area postrema contained the highest level of ANP binding sites $(2.27 \pm$ $0.55 \mathrm{fmol} / \mathrm{mg}$ protein), while the subfornical organ contained a moderately high level $(1.51 \pm 0.26 \mathrm{fmol} / \mathrm{mg}$ protein $)$. The median eminence possessed a moderate level of ANP binding sites, whereas the subcommissural organ and the pineal gland contained low levels of ${ }^{125}$ I-ANP-28 binding.

Within the midbrain and brain stem, the interpeduncular nucleus contained the highest level of ANP binding sites $(0.86 \pm$ $0.08 \mathrm{fmol} / \mathrm{mg}$ protein). The substantia nigra, central gray, and both colliculi contained low to moderate levels of ANP binding sites. Individual nuclei of the reticular formation (lateral, medullary, paragigantocellular) possessed low to moderate levels of ANP binding sites, as did the subregions of the raphe and the superior and inferior olives. All motor and sensory nuclei of the cranial nerves examined contained low levels of ${ }^{12}$ I-ANP-28.

Within the diencephalon, the highest levels of ANP binding sites were localized within the habenular nuclei $(1.05 \pm 0.14$ $\mathrm{fmol} / \mathrm{mg}$ protein). Most other thalamic nuclei contained low to moderate levels of ANP binding sites. In comparison to the thalamus, the nuclei and subregions of the hypothalamus contained predominantly low levels of ANP binding sites. The arcuate, paraventricular, ventromedial, and posterior nuclei and the preoptic, anterior, and lateral areas all contained between 0.3 and $0.4 \mathrm{fmol} / \mathrm{mg}$ protein of ${ }^{125} \mathrm{I}-\mathrm{ANP}-28$ binding sites.

The limbic forebrain contained low levels of ANP binding sites. Individual nuclei of the amygdala were homogeneously labeled with low levels of ${ }^{125}$ I-ANP-28. Although the ventral hippocampal commissure had moderate levels of ANP binding sites $(0.70 \pm 0.10 \mathrm{fmol} / \mathrm{mg}$ protein $)$, all subfields of the hippocampus, as well as the dentate gyrus and subiculum, contained low levels. The septum, olfactory tubercle, and bed nucleus of the stria terminalis also possessed low levels of specific binding of ${ }^{125} \mathrm{I}-\mathrm{ANP}-28$.

The basal ganglia (accumbens nucleus, ventral palladium, and globus pallidus) all possessed less than $0.4 \mathrm{fmol} / \mathrm{mg}$ protein of ANP binding sites. The caudate was homogeneously labeled by ${ }_{125}$ I-ANP-28 at a low level $(0.12 \pm 0.02 \mathrm{fmol} / \mathrm{mg}$ protein). Similarly, the cerebellum was homogeneously labeled $(0.28 \pm 0.03$ $\mathrm{fmol} / \mathrm{mg}$ protein) in low density, with no difference observed between the molecular and granular layers.

The cerebral cortex contained low levels of ${ }^{125}$ I-ANP-28 binding sites. Striate cortex was the only region of cortex that contained a moderate level of ANP binding sites $(0.52 \pm 0.08 \mathrm{fmol} /$ $\mathrm{mg}$ protein). All other regions of cortex examined (cingulate, frontal, olfactory) possessed low levels ( $<0.4 \mathrm{fmol} / \mathrm{mg}$ protein) of ANP binding sites. No variation between individual layers of the cerebral cortex was observed.

\section{Discussion}

Utilizing the technique of quantitativc autoradiography, this report describes the discrete and heterogeneous distribution of ANP receptors throughout the rat brain (Fig. 1). The highest levels of ANP receptors were localized to the circumventricular organs and the olfactory apparatus (Table 2). Moderate levels of ANP receptors werc found in the midbrain and brain stem, while low levels were localized throughout the forebrain, diencephalon, basal ganglia, cortex, and cerebellum.

It is particularly interesting that the distribution of ANP receptors in the CNS includes the subfornical organ and area postrema. Utilizing behavioral and physiological methods, these structures have been determined to be part of a neural network mediating water and sodium balance (Hyde and Miselis, 1984; Miselis, 1981, 1982). In addition, the subfornical organ and the area postrema have been shown to possess high levels of angiotensin II receptors (Mendelsohn et al., 1984), and sites of angiotensin II action on the CNS. Lesions of the subfornical organ in rat abolish the dipsogenic response to peripheral angiotensin II administration (Simpson, 1981), while area postrema lesions result in an exaggerated drinking response to this peptide (Edwards and Ritter, 1982). Thus, the effect of angiotensin II binding to the area postrema appears to antagonize the dipsogenic mechanism of angiotensin II reception at the subfornical organ. This phenomenon may also occur in the ANP system, since lesions of the area postrema evoke natriuresis, while lesions of the anteroventral third ventricle region (AV3V), which contains many afferent and efferent connections with the subfornical organ, elicit hypernatremia (Buggy and Johnson, 1977; Hyde and Miselis, 1984). Such a system would constitute another source of feedback control by cardiac atria of the neuroendocrine regulation of extracellular volume, in addition to the modulation of ADH secretion by atrial stretch receptors (Ledsome, 1985).

In contrast to the distribution of ANP receptors in the rat $\mathrm{CNS}$, immunohistochemical studies have revealed relatively high 
Table 2. Relative concentrations of 12 I-AP-28 binding sites in rat brain determined by quantitative autoradiography

\begin{tabular}{|c|c|}
\hline Structure & $\begin{array}{l}{ }^{125} \mathrm{I}-\mathrm{ANP}-28 \text { bound } \\
\text { (fmol/mg protein) }\end{array}$ \\
\hline \multicolumn{2}{|l|}{ Olfactory apparatus } \\
\hline \multicolumn{2}{|l|}{ Olfactory bulb } \\
\hline Plexiform layer & $1.97 \pm 0.11$ \\
\hline Granular layer & $0.70 \pm 0.07$ \\
\hline Glomerular layer & $0.76 \pm 0.19$ \\
\hline Olfactory nerve & $0.65 \pm 0.15$ \\
\hline Accessory olfactory bulb & $3.13 \pm 0.10$ \\
\hline Olfactory nuclei & $0.36 \pm 0.04$ \\
\hline Lateral olfactory tract & $1.24 \pm 0.13$ \\
\hline \multicolumn{2}{|l|}{ Cortex } \\
\hline Frontal cortex & $0.18 \pm 0.04$ \\
\hline Primary olfactory cortex & $0.16 \pm 0.02$ \\
\hline \multicolumn{2}{|l|}{ Corpus callosum } \\
\hline Medial & $0.90 \pm 0.02$ \\
\hline Lateral & $0.59 \pm 0.02$ \\
\hline Anterior cingulate cortex & $0.40 \pm 0.05$ \\
\hline Posterior cingulate cortex & $0.28 \pm 0.06$ \\
\hline Splenium corpus callosum & $1.09 \pm 0.10$ \\
\hline Striate cortex & $0.52 \pm 0.08$ \\
\hline \multicolumn{2}{|l|}{ Limbic forebrain } \\
\hline Olfactory tubercle & $0.18 \pm 0.05$ \\
\hline \multicolumn{2}{|l|}{ Lateral septum } \\
\hline Dorsal & $0.25 \pm 0.06$ \\
\hline Intermediate & $0.24 \pm 0.07$ \\
\hline Ventral & $0.22 \pm 0.07$ \\
\hline Medial septum & $0.30 \pm 0.05$ \\
\hline Diagonal band of Broca & $0.35 \pm 0.06$ \\
\hline Anterior commissure & $0.69 \pm 0.12$ \\
\hline Bed nucleus of the stria terminalis & $0.28 \pm 0.06$ \\
\hline Ventral hippocampal commissure & $0.70 \pm 0.10$ \\
\hline \multicolumn{2}{|l|}{ Hippocampus } \\
\hline $\mathrm{CA} 3$ & $0.28 \pm 0.02$ \\
\hline Dentate gyrus & $0.29 \pm 0.03$ \\
\hline \multicolumn{2}{|l|}{ Amygdala } \\
\hline Central nucleus & $0.21 \pm 0.10$ \\
\hline Lateral nucleus & $0.24 \pm 0.02$ \\
\hline \multicolumn{2}{|l|}{ Basal ganglia } \\
\hline Caudate putamen & $0.12 \pm 0.02$ \\
\hline Accumbens nucleus & $0.22 \pm 0.02$ \\
\hline Ventral palladium & $0.22 \pm 0.04$ \\
\hline \multicolumn{2}{|l|}{ Circumventricular organs } \\
\hline Subfornical organ & $1.51 \pm 0.26$ \\
\hline Median eminence & $0.52 \pm 0.11$ \\
\hline Area postrema & $2.27 \pm 0.55$ \\
\hline \multicolumn{2}{|l|}{ Hypothalamus } \\
\hline Periventricular nucleus & $0.33 \pm 0.05$ \\
\hline Medial preoptic area & $0.32 \pm 0.04$ \\
\hline Lateral preoptic area & $0.34 \pm 0.06$ \\
\hline Anterior hypothalamic area & $0.17 \pm 0.06$ \\
\hline Lateral hypothalamic area & $0.25 \pm 0.02$ \\
\hline Supraoptic nucleus & $0.33 \pm 0.04$ \\
\hline Paraventricular nucleus & $0.30 \pm 0.03$ \\
\hline Arcuate nucleus & $0.40 \pm 0.06$ \\
\hline Ventromedial nucleus & $0.30 \pm 0.04$ \\
\hline
\end{tabular}

Table 2. Continued

Structure

${ }^{125} \mathrm{I}-\mathrm{ANP}-28$ bound (fmol/mg protein)

Dorsomedial nucleus

$0.32 \pm 0.06$

Posterior nucleus

$0.31 \pm 0.08$

Mammillary nuclei

$0.38 \pm 0.12$

Thalamus

Paraventricular nucleus $\quad 0.68 \pm 0.02$

Anteroventral nucleus

Anteromedial nucleus

$0.45 \pm 0.05$

Ventrolateral nucleus

$0.32 \pm 0.02$

Ventroposterolateral nucleus

$0.43 \pm 0.03$

Lateral dorsal thalamus

$0.50 \pm 0.04$

Lateral posterior thalamus

$0.34 \pm 0.06$

Habenular nucleus

$0.24 \pm 0.05$

$1.05 \pm 0.14$

Midbrain

Substantia nigra

$0.36 \pm 0.09$

Central gray

Superior colliculus

$0.41 \pm 0.09$

$0.51 \pm 0.12$

Interpeduncular nucleus

$0.86 \pm 0.08$

Cranial nerves and nuclei

Optic nerve

$0.45 \pm 0.03$

Optic chiasm

Motor nucleus (5)

Principal sensory nucleus (5)

$0.40 \pm 0.05$

$0.47 \pm 0.13$

$0.48 \pm 0.08$

Facial nucleus (7)

$0.53 \pm 0.10$

$0.43 \pm 0.06$

$0.34 \pm 0.06$

$0.37 \pm 0.04$

Solitary nucleus (10)

Hypoglossal nucleus (12)

$0.56 \pm 0.10$

$0.56 \pm 0.15$

$0.55 \pm 0.09$

$0.55 \pm 0.13$

$0.58 \pm 0.08$

$0.47 \pm 0.11$

$0.44 \pm 0.05$

$0.53 \pm 0.09$

$0.55 \pm 0.10$

$0.35 \pm 0.04$

$0.40 \pm 0.07$

$0.28 \pm 0.03$

Cerebellum

Frozen $32 \mu \mathrm{m}$ thick brain sections were labeled as described in Materials and Methods with 50 pM ${ }^{125}$ I-AP-28, and apposed against LKB Ultrofilm for $5 \mathrm{~d}$ to generate autoradiograms. Brain sections $(32 \mu \mathrm{m})$ were cut at $500 \mu \mathrm{m}$ intervals corresponding to coronal levels of the atlas of Paxinos and Watson (1982). Serially cut sections at each level were used for determination of total and nonspecific binding. Nonspecific binding was subtracted from each structure at each level Values are means \pm SE from readings taken from 4 rat brains.

levels of ANP-related peptides in the preoptic area and the pontine tegmentum (Saper et al., 1985), sites of low levels of ANP receptors. This disparity in localization between a peptide and its receptor has been observed previously, and several explanations have been proposed (Kuhar and Unnerstall, 1985). However, the existence of ANP-related peptides in the AV3V region of the preoptic area is especially intriguing, since fibers from the subfornical organ extend directly to the AV3V (Miselis, 1981). The subfornical organ also has afferent connections to the paraventricular nucleus and lateral area of the hypothala- 


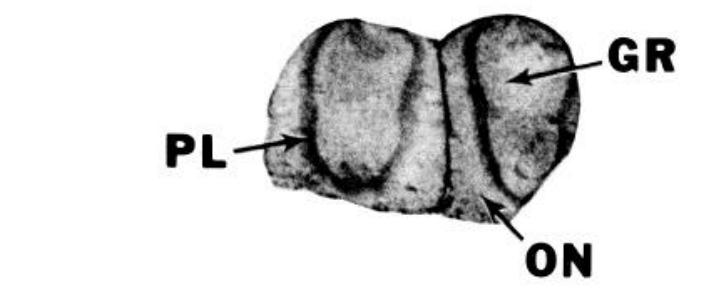

A
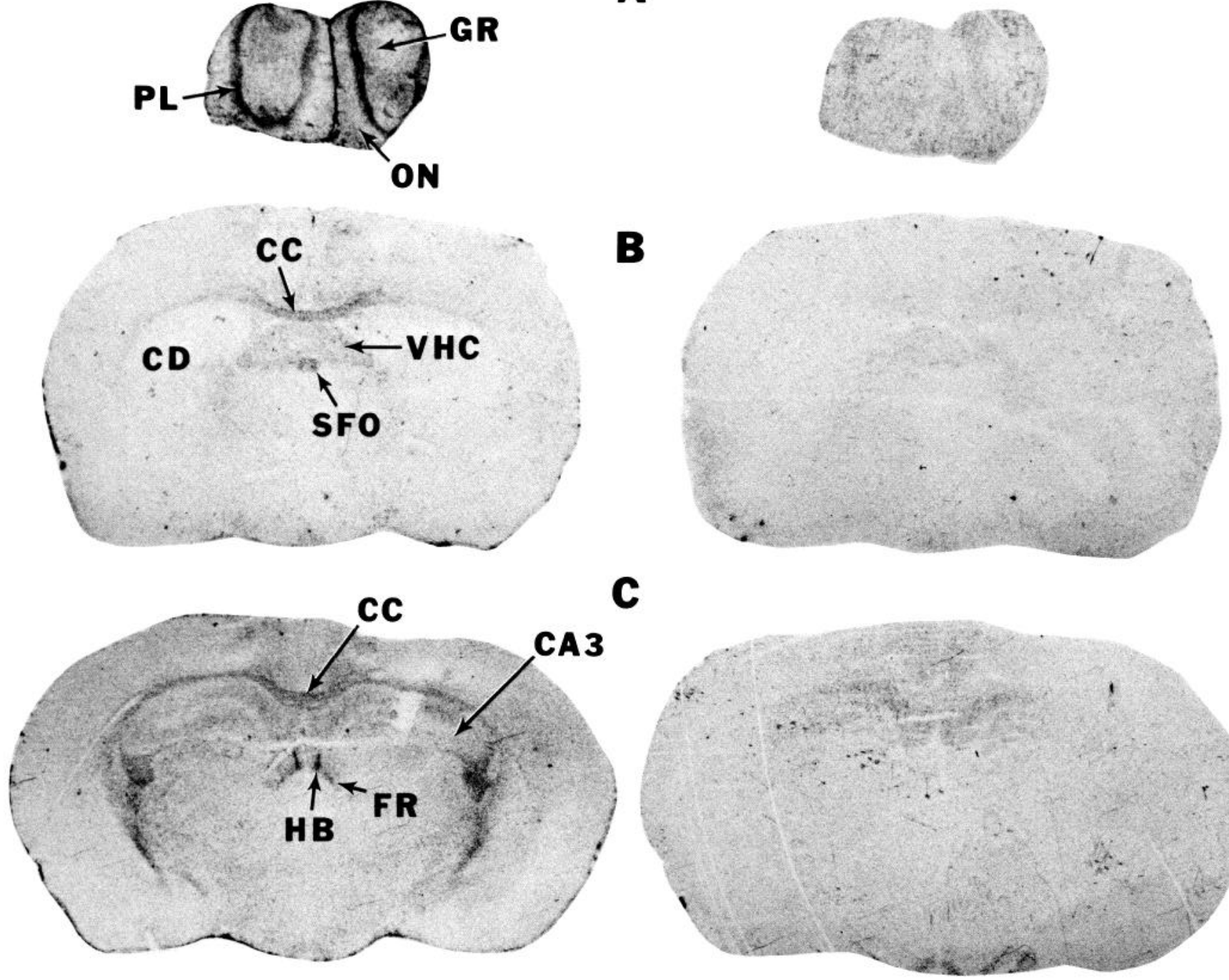

C
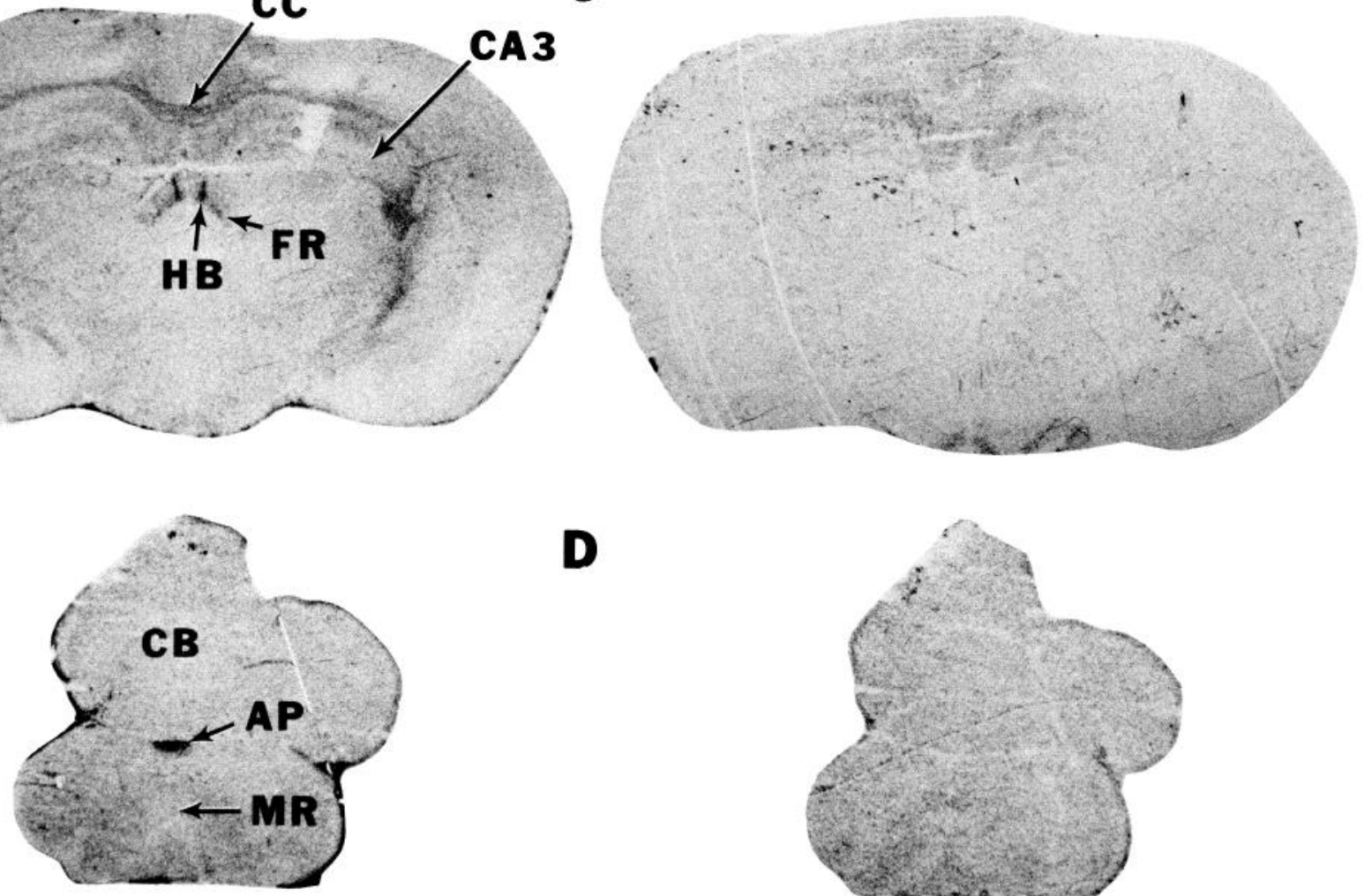

D
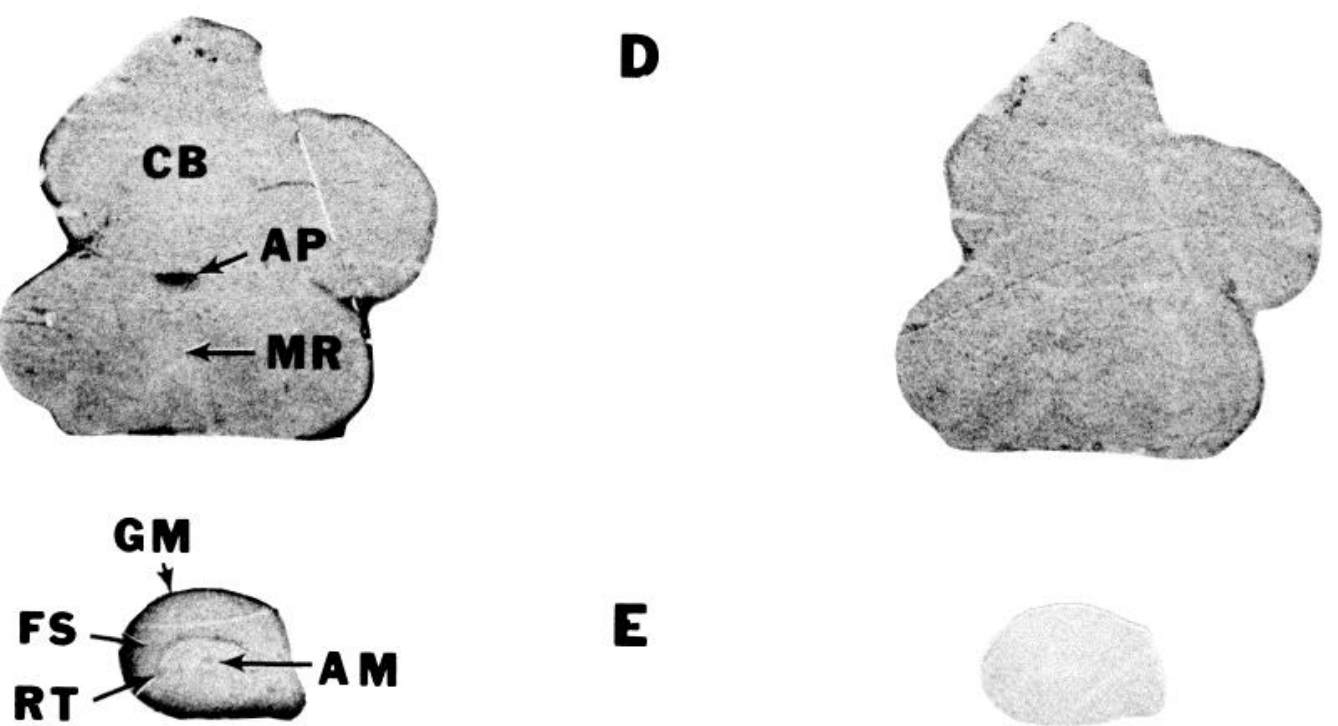

$\mathbf{E}$

Figure 1. Distribution of AP-28 receptors in rat brain and adrenal gland determined by quantitative autoradiography. Frozen $32 \mu \mathrm{m}$ thick sections of rat brain and adrenal gland were labeled, as described in Materials and Methods, with 50 pM ${ }^{125}$ I-AP-28 and apposed to LKB Ultrofilm for $5 \mathrm{~d}$ to generate autoradiograms. Sections representing total binding are on the left, while sections representing nonspecific binding are on the right. $A-$ $D$, Coronal level from the atlas of Paxinos and Watson (1982). All brain sections are presented at the same magnification. $A$, Level 2: $P L$, plexiform 
mus, the bed nuclcus of the stria terminalis, and the perifornical region (Miselis, 1981; Weiss et al., 1984), all areas shown to possess neurons that contain ANP immunoreactivity (Saper et al., 1985). In addition, a major projection from the area postrema extends to the lateral parabranchial nucleus (Shapiro and Miselis, 1985), which has been shown to contain fibers from the AV3V that contain ANP-immunoreactive material (Saper et al., 1985).

Thus, it is apparent that numerous connections exist between ANP receptor-containing and ANP-related peptide-containing structures. Also, fibers from the subfornical organ extend to the organum vasculosum of the lamina terminalis (OVLT), a structure postulated to be directly involved in peripheral ANP feedback control of CNS fluid balance regulation (Saper et al., 1985). Although it is difficult to visualize the OVLT in coronal sections, in several sections we observed moderate to moderately high levels of ANP binding sites in the OVLT region. Thus, the OVLT itself might be included in the group of circumventricular organs that contain ANP receptors.

Another region containing high levels of ANP receptors, the olfactory apparatus, has few known functions other than olfaction. However, the olfactory bulb contains numerous neuropeptides and peptide receptors. For example, insulin, luteinizing hormone-releasing hormone, substance $\mathrm{P}$, Met-enkephalin, TRH, somatostatin, and angiotensin II are all highly concentrated in the olfactory bulb (Bogen et al., 1982; Brownstein et al., 1975, 1976; Havrankova et al., 1978; Jennes and Stumpf, 1980; Kreider et al., 1981; Lind et al., 1985). Peptide receptors, such as those for TRH and cholecystokinin, are also present in the olfactory bulb in high levels (Gaudreau et al., 1983; Manaker et al., 1985; Van Dijk et al., 1984; Zarbin et al., 1983a). This concentration of peptides and peptide receptors may indicate that the olfactory apparatus utilizes a rich variety of peptides in the neurochemistry of olfaction, or it could suggest that the olfactory bulb may have other (as yet undiscovered) functions.

ANP binding was also found in the lateral region of the medial habenular nucleus of the thalamus and the interpeduncular nucleus of the midbrain. Interestingly, these 2 nuclei are connected by the fasciculus retroflexus, which also contains ANP binding sites (Fig. 1). The function of ANP receptors in these areas is not known, but the presence of ANP binding in all 3 structures suggests that the habenular and interpeduncular nuclei may be part of an integrated network, functionally as well as structurally.

It has been discovered that different forms of ANP-related peptides are present in various tissues. In the atria, ANP-immunoreactive material has been found predominately in a 1015 kilodalton $(\mathrm{kDa})$ form, while smaller forms have been localized to the plasma $(3 \mathrm{kDa})$ and hypothalamus $(1.5 \mathrm{kDa})$ (Glembotski et al., 1985; Morii et al., 1985; Tanaka et al., 1984). Thus, cardiac-derived ANP-related peptides in the plasma (the $3 \mathrm{kDa}$ form) may act on the CNS through receptors in the subfornical organ and area postrema (both circumventricular organs outside the blood-brain barrier), perhaps similarly to the way that angiotensin II acts on these structures (Edwards and Ritter, 1982; Simpson, 1981). In contrast, the different forms of ANP found within the brain (such as the hypothalamus) may interact with receptors found in the olfactory apparatus and hindbrain, much like classical neurotransmitters or neuromodulators.

Given the relative lack of data on the physiological effects of ANP in the CNS, we cannot now rule out the possibility that these binding sites in the CNS are merely acceptors for ANP, and not ANP receptors (Quirion et al., 1984). It is even possible that these binding sites may not be on neurons, but on glia or capillaries, although the pattern of binding, for example, in the olfactory bulb would argue against this hypothesis. In addition, onc recent study did demonstrate that basal relcasc of argininc vasopressin from the neural lobe of the pituitary was decreased when $2 \mathrm{nmol}$ AP III were injected into the third ventricle of conscious male rats (Samson, 1985). This would indicate that ANP receptors are indeed involved in brain function. Further electrophysiological and microinjection studies are needed to demonstrate that these binding sites are biologically relevant receptors that mediate the actions of ANP on the CNS.

It has been established that, in some bioassay systems, the $\mathrm{COOH}$-terminal tyrosine of Pro-ANP-derived peptides is important to the bioactivity of these peptides (Garcia et al., 1985). In the present study, (3-125I-iodotyrosyl $\left.{ }^{28}\right)$ rat ANP-28 was used as the radiolabeled ligand. The presence of the large iodine atom attached to the $\mathrm{COOH}$-terminal tyrosine might have resulted in a different affinity for the receptor, as opposed to the native peptide, as well as a different pharmacological profile in competition experiments. Since ${ }^{127} \mathrm{I}$-ANP was shown to have equal potency to noniodinated ANP in the rat and rabbit aorta bioassay (Napier et al., 1984) and the $\mathrm{IC}_{50}$ values obtained in the present study using unlabeled ligand are similar to the ${ }^{125}$ I-ANP$28 K_{\mathrm{d}}$ values, the modification of this tyrosine apparently does not radically change the properties of the peptide as a ligand. However, the $K_{\mathrm{d}}$ values obtained in the present study do seem to differ from those in some other studies. Napier et al. (1984) obtained $K_{\mathrm{d}}$ values of $50 \mathrm{pm}$ for ANP-28 binding to partially purified kidney membranes, while our higher $K_{\mathrm{d}}$ and $\mathrm{IC}_{50}$ values were obtained by binding to sections of olfactory bulb and adrenal mash and tissue sections. Significant differences in $K_{\mathrm{d}}$ values have been obtained previously in other systems when these 2 different binding protocols have been compared. For example, when binding of quinuclidinyl benzilate to muscarinic receptors was examined, $K_{\mathrm{d}}$ values of 14,270 , and 500 pм were obtained in experiments using prepared membranes and 10 and $32 \mu \mathrm{m}$ sections, respectively (Luthin and Wolfe, 1984; Rainbow et al., 1982; Wamsley et al., 1981). Thus, it appears that the inability of the ligand to penetrate into tissue sections may be implicated in the higher $K_{d}$ values obtained as tissue thickness increases.

In the present study, specific binding to white matter structures was observed, and this binding appeared to be discrete and heterogeneous as well. For example, while the corpus callosum and olfactory apparatus white matter contained moderate to moderately high levels of ANP receptors, the cranial nerves examined and the cerebellar and cerebral peduncles contained much lower levels. In addition, within the corpus callosum itself, the medial corpus callosum contained higher levels than did the more lateral regions. Thus, it seems that these binding sites within white matter are not simply nonspecific binding, but represent actual specific binding sites. While the function of ANP binding sites within white matter is not known, they could represent receptors in transit to distal regions, as reported for other peptides and classical neurotransmitters (Laduron, 1980; Young et al., 1980; Zarbin et al., 1981, 1983b). For example, the receptors present in the lateral olfactory tracts could be in transit from or to the olfactory bulb, which contains high levels of ANP receptors. It is possible that these binding sites might not be actual receptors, and may be of lower affinity. Indeed,

\footnotetext{
layer of olfactory bulb; $G R$, granular layer of olfactory bulb; $O N$, olfactory nerve. $B$, Level 16: $S F O$, subfornical organ; $C C$, corpus callosum; $V H C$, ventral hippocampal commissure; $C D$, caudate. $C$, Level $21: H B$, habenular nucleus of the thalamus; $C C$, corpus callosum; $C A 3$, level $C A 3$ of the hippocampus; $F K$, fasciculus retroflexus. $D$, Level $42: A P$, area postrema; $C B$, cerebellum; $M R$, medullary reticular formation. $E$, Adrenal section: $G M$, zona glomerulosa; $F S$, zona fasciculata; $R T$, zona reticulata; $A M$, adrenal medulla.
} 
Quirion et al. (1984) found nondisplaceable binding in white matter, although a different peptide was used to determine nonspecific binding than in the present study.

In conclusion, binding sites for ANP have been localized to both peripheral and CNS regions. The localization of specific binding sites to the circumventricular organs suggests that ANPrelated peptides may play a key role in integrating the abilities of the nervous and endocrine systems to regulate fluid and electrolyte balance. Further characterization of the factors responsible for the regulation of both peripheral and central ANP and ANP receptor levels will facilitate an understanding of the role of ANP in the heart and CNS as an important regulator of fluid balance.

\section{References}

Atlas, S. A., H. D. Kleinert, M. J. Camargo, A. Januszewicz, J. E. Sealy, J. H. Laragh, J. W. Schilling, J. A. Lewicki, L. K. Johnson, and T. Maack (1984) Purification, sequencing and synthesis of natriuretic and vasoactive rat atrial peptide. Nature 309: 717-719.

Bogen, N., N. Brecha, C. Gall, and H. J. Karten (1982) Distribution of enkephalin-like immunoreactivity in the rat main olfactory bulb. Neuroscience 7: 895-906.

Brownstcin, M., A. Arimura, H. Sato, A. V. Schally, and J. S. Kizer (1975) The regional distribution of somatostatin in the rat brain. Endocrinology 96: 1456-1461.

Brownstein, M. J., A. Mroz, J. Kizer, M. Palkovils, and S. E. Leeman (1976) Regional distribution of substance $P$ in the brain of the rat. Brain Res. 116: 299-305.

Buggy, J., and A. K. Johnson (1977) Preoptic-hypothalamic periventricular lesions: Thirst deficits and hypernatremia. Am. J. Physiol. 233: R44-R52.

Currie, M. G., D. M. Geller, B. R. Cole, J. G. Boylan, W. YuSheng, S. W. Holmberg, and P. Needleman (1983) Bioactive cardiac substances: Potent vasorelaxant activity in mammalian atria. Science 221: 71-73.

Currie, M. G., D. M. Geller, B. R. Cole, N. R. Siegel, K. F. Fok, S. P. Adams, S. R. Eubanks, and G. R. Galluppi (1984) Purification and sequence analysis of bioactive atrial peptides (atriopeptins). Science 223: 67-69.

DeBold, A. J., H. B. Borenstein, A. T. Veress, and H. Sonnenberg (1981) $A$ rapid and potent natriuretic response to intravenous injection of atrial myocardial extract in rats. Life Sci. 28: 89-94.

DeLean, A., J. Gutkowska, N. McNicoll, P. W. Schiller, M. Cantin, and J. Genest (1984) Characterization of specific receptors for atrial natriuretic factor in bovine adrenal zona glomerulosa. Life Sci. 35: 2311-2318.

Edwards, G. L., and R. C. Ritter (1982) Area postrema lesions increase drinking to angiotensin and extracellular dehydration. Physiol. Behav. 29: 943-947.

Garcia, R., G. Thibault, N. G. Seidah, C. Lazure, M. Cantin, J. Genest, and M. Chretien (1985) Structure-activity relationships of atrial natriuretic factor (ANF). II. Effect of chain-length modifications on vascular reactivity. Biochem. Biophys. Res. Commun. 126: 178-184.

Gaudreau, P., R. Quirion, S. St-Pierre, and C. B. Pert (1983) Characterization and visualization of cholecystokinin receptors in rat brain using $\left[{ }^{3} \mathrm{H}\right]$ pentagastrin. Peptides 4: 755-762.

Glembotski, C. C., G. M. Wildey, and T. R. Gibson (1985) Molecular forms of immunoactive atrial natriuretic peptide in the rat hypothalamus and atrium. Biochem. Biophys. Res. Commun. 129: 671678.

Havrankova, J., D. Schemechel, J. Roth, and M. Brownstein (1978) Identification of insulin in rat brain. Proc. Natl. Acad. Sci. USA 75: $5737-5741$

Hirata, Y., M. Tomita, H. Yoshimi, and M. Ikeda (1984) Specific receptors for atrial natriuretic factor (ANF) in cultured vascular smooth muscle cells of rat aorta. Biochem. Biophys. Res. Commun. 125: 562568.

Hyde, T. M., and R. R. Miselis (1984) Area postrema and adjacent nucleus of the solitary tract in water and sodium balance. Am. J. Physiol. 247 (Regulatory Integrative Comp. Physiol. 16): R173-R182.

Iversen, L. L. (1983) Non-opioid neuropeptides in mammalian CNS. Annu. Rev. Pharmacol. Toxicol. 23: 1-27.
Jennes, L., and W. E. Stumpf (1980) LHRH-systems in the brain of the golden hamster. Cell Tissue Res. 209: 239-256.

Jacobowitz, D. M., G. Skofitsch, H. R. Keiser, R. L. Eskay, and N. Zamir (1985) Evidence for the existence of atrial natriuretic factorcontaining neurons in the rat brain. Neuroendocrinology 40: 92-94.

Kreider, M. S., A. Winokur, and N. R. Kreiger (1981) The olfactory bulb is rich in TRH immunoreactivity. Brain Res. 217: 69-77.

Krieger, D. T. (1983) Brain peptides: What, where, and why? Science 222: 975-985.

Kuhar, M. J., and J. R. Unnerstall (1985) Quantitative receptor mapping by autoradiography: Some current technical problems. Trends Neurosci. 8: 49-53.

Laduron, P. (1980) Axoplasmic transport of muscarinic receptors. Nature 286: 287-288.

Ledsome, J. R. (1985) Atrial receptors, vasopressin and blood volume in the dog. Life Sci. 36: 1315-1330.

Lind, R. W., L. W. Swanson, and D. Ganten (1985) Organization of angiotensin II immunoreactive cells and fibers in the rat central nervous system. An immunohistochemical study. Neuroendocrinology 40: $2-24$.

Luthin, G. R., and B. B. Wolfe (1984) $\left[{ }^{3} \mathrm{H}\right]$ Pirenzepine and $\left[{ }^{3} \mathrm{H}\right]$ quinuclidinyl benzilate binding to brain muscarinic receptors. Mol. Pharmacol. 26: 164-169.

Maki, M., R. Takayanagi, K. S. Misono, K. N. Pandey, C. Tibbetts, and T. Inagami (1984) Structure of rat atrial natriuretic factor precursor deduced from cDNA sequence. Nature 309: 722-724.

Manaker, S., A. Winokur, W. H. Rostene, and T. C. Rainbow (1985) Autoradiographic localization of thyrotropin-releasing hormone receptors in the rat central nervous system. J. Neurosci. 5: 167-174.

Matsuoka, H., M. Isii, T. Sugimoto, Y. Hirata, T. Sugimoto, K. Kangawa, and H. Matsuo (1985) Inhibition of aldosterone production by $\alpha$-human atrial natriuretic polypeptide is associated with an increase in cGMP production. Biochem. Biophys. Res. Commun. 127. $1052-1056$.

Mendelsohn, F. A. O., R. Quirion, J. M. Saavedra, G. Aquilera, and K. J. Catt (1984) Autoradiographic localization of angiotensin II receptors in rat brain. Proc. Natl. Acad. Sci. USA 81: 1575-1579.

Miselis, R. R. (1981) The efferent projections of the subfornical organ of the rat: A circumventricular organ within a neural network subserving water balance. Brain Res. 230: 1-23.

Miselis, R. R. (1982) Recent advances in subfornical organ morphology. II. Neural connectivity of the subfornical organ. Front. Horm. Res. 9: 79-87.

Morii, N., K. Nakao, A. Sugawara, M. Sakamoto, M. Suda, M. Shimokura, Y. Kiso, M. Kihara, Y. Yamori, and H. Imura (1985) Occurrence of atrial natriuretic polypeptide in brain. Biochem. Biophys. Res. Commun. 127: 413-419.

Napier, M. A., R. L. Vandlen, G. Albers-Schonberg, R. F. Nutt, S. Brady, T. Lyle, R. Winquist, E. P. Faison, L. A. Heinel, and E. H. Blaine (1984) Specific membrane receptors for atrial natriuretic factor in renal and vascular tissues. Proc. Natl. Acad. Sci. USA 81: 59465950.

Oikawa, S., M. Imai, A. Ueno, S. Tanaka, T. Noguchi, H. Nakazato, K. Kangawa, A. Fukuda, and H. Matsuo (1984) Cloning and sequence analysis of CDNA encoding a precursor for human atrial natriuretic polypeptide. Nature 309: 724-726.

Paxinos, G., and C. Watson (1982) The Rat Brain in Stereotaxic Coordinates, Academic, New York.

Quirion, R., M. Dalpe, A. DeLean, J. Gutkowska, M. Cantin, and J. Genest (1984) Atrial natriuretic factor (ANF) binding sites in brain and related structures. Peptides 5: 1167-1172.

Rainbow, T. C., W. V. Bleisch, A. Biegon, and B. S. McEwen (1982) Quantitative densitometry of neurotransmitter receptors. J. Neurosci. Methods 5: 127-138.

Rainbow, T. C., A. Biegon, and D. J. Berk (1984) Quantitative receptor autoradiography with tritium-labeled ligands: Comparison of biochemical and densitometric measurements. J. Neurosci. Methods 11 . 231-241.

Samson, W. K. (1985) Dehydration-induced alterations of CNS vasopressin and atrial natriuretic factor content. Endocrinology (Suppl.) 116: 157 (abstr. 626).

Saper, C. B., D. G. Standaert, M. G. Currie, D. Schwartz, D. M. Geller, and P. Needleman (1985) Atriopeptin-immunoreactive neurons in the brain: Presence in cardiovascular regulatory areas. Science 227: 1047-1049. 
Shapiro, R. E., and R. R. Miselis (1985) The central neural connections of the area postrema of the rat. J. Comp. Neurol. 234: 344-364.

Simpson, J. B. (1981) The circumventricular organs and the central actions of angiotensin. Neuroendocrinology 32: 248-256.

Tanaka, I., K. S. Misono, and T. Inagami (1984) Atrial natriuretic factor in rat hypothalamus, atria, and plasma: Determination by specific radioimmunoassay. Biochem. Biophys. Res. Commun. 124:663668.

Unnerstall, J. R., D. L. Niehoff, M. J. Kuhar, and J. Palacios (1982) Quantitative receptor autoradiography using $\left[{ }^{3} \mathrm{H}\right]$ Ultrofilm: Application to multiple benzodiazepine receptors. J. Neurosci. Methods 6 : 59-73.

Van Dijk, A., J. G. Richards, A. Trzeciak, D. Gillessen, and H. Mohler (1984) Cholecystokinin receptors: Biochemical demonstration and autoradiographical localization in rat brain and pancreas using $\left[{ }^{3} \mathrm{H}\right]$ cholecystokinin $_{8}$ as radioligand. J. Neurosci. 4: 1021-1033.

Wamsley, J. K., M. L. Lewis, W. S. Young, and M. J. Kuhar (1981) Autoradiographic localization of muscarinic-cholinergic receptors in rat brainstem. J. Neurosci. 1: 176-191.
Weiss, M. L., R. E. Shapiro, and R. R. Miselis (1984) Subfornical organ (SFO) connectivity examined using cholera toxin-horseradish peroxidase conjugate. Soc. Neurosci. Abstr. 10: 609 (abstr. 179.2)

Yamanka, M., B. Greenberg, L. Johnson, J. Seilhamer, M. Brewer, T. Friedemann, J. Miller, S. Atlas, J. Laragh, J. Lewicki, and J. Fiddes (1984) Cloning and sequence analysis of the cDNA for the rat atrial natriuretic factor precursor. Nature 309: 719-722.

Young, W. S., III, J. K. Wamsley, M. A. Zarbin, and M. J. Kuhar (1980) Opioid receptors undergo axonal flow. Science 210: 76-78.

Zarbin, M. A., J. K. Wamsley, R. B. Innis, and M. J. Kuhar (1981) Cholecystokinin receptors: Presence and axonal flow in the rat vagus nerve. Life Sci. 29: 698-705.

Zarbin, M. A., R. B. Innis, J. K. Wamsley, S. H. Snyder, and M. J. Kuhar (1983a) Autoradiographic localization of cholecystokinin receptors in rodent brain. J. Neurosci. 3: 877-906.

Zarbin, M. A., J. M. Palacios, J. K. Wamsley, and M. J. Kuhar (1983b) Axonal transport of $\beta$-adrenergic receptors. Antero- and retrogradely transported receptors differ in agonist affinity and nucleotide sensitivity. Mol. Pharmacol. 24: 341-348. 